\title{
LETTER
}

\section{Learning from mistakes during the pandemic: the Lombardy lesson}

\author{
Alberto Zangrillo ${ }^{1}$ and Luciano Gattinoni $2^{2^{*}}$ (D)
}

(c) 2020 The Author(s)

\section{Dear Editor,}

Pandemic SARS-CoV-2 is slowly declining after causing thousands of deaths in the World and in Italy, with an ICU mortality close to $50 \%$ [1]. In a matter of days, Italy ICU capacity ( $\sim 5000$ beds) almost doubled. Now that hospitals are slowly returning to normality, as intensivists we should draw some lessons. Epidemics are recurring with remarkable regularity (SARS 2003, H1N1 2009, MERS 2012, SARS-CoV-2 2019): we must be ready to address the next outbreaks effectively and timely.

In Lombardy, surgical theatres and regular wards were converted to ICUs and intermediate units. The shortage of specialized personnel was addressed creating a mixed staff, with experienced ICU doctors and nurses working alongside younger residents and doctors from different specialties. Field hospitals were built in the close neighbourhood of the main city hospitals (Bergamo, Cremona, Milano, San Raffaele). In addition, a stand-alone 600 beds ICU (21 M€) was built in Milan Fair Area: a total of 25 patients were admitted. Similarly, the NHS built 500 beds in the ExCel Convention Center in London (cost undeclared) in which 41 patients were admitted. In New York City, two temporarily hospitals were built on Long Island (250 M\$) with no patients admitted. All these structures, as similar others in Barcelona and Madrid, are now ready to be dismantled.

In Lombardy, the mortality rate was fourfold higher than in the neighbouring Veneto region [2], despite the similar timing of outbreak. Several reasons may account for this phenomenon. We believe, however, that a more effective territorial medical organization may have

\footnotetext{
*Correspondence: gattinoniluciano@gmail.com

${ }^{2}$ Department of Anesthesiology, Intensive Care and Emergency Medicine, Medical University of Göttingen, Göttingen, Germany

Full author information is available at the end of the article
}

mitigated SARS-CoV-2 impact. This could have been a primary reason explaining low mortality rates of COVID19 in Germany.

In such a pandemic, the key role of intensive care is to provide support, "buying time" for patients to heal spontaneously. This is especially important when a specific, effective drug does not exist-as currently the case with COVID-19. It is possible that a fraction of the ICU mortality during epidemics is due to the overwhelming number of patients. Indeed, the sudden increase in ICU beds deployment with consequent "dilution" of trained personnel implies a decrease in intensity/adequacy of care, regardless the huge personal effort of single individuals.

Before the pandemic, Italy provided 8.8 per 100,000 population, a data in line with that of most other European countries [3]. A pressing shortage of ICU beds has merited front page news once before in Italy's recent history: $2009 \mathrm{H} 1 \mathrm{~N} 1$ pandemic was a major stress test for Italian healthcare system. Lesson learned? Not quite but the creation of ECMOnet [4].

Is it a solution to increase ICU beds and if so, by how much? Italian government is now committing to create 3500 ICU beds (+70\%). International standards would require training and hiring 12,250 nurses and 3200 doctors. Achieving these numbers in a short time span is unrealistic. Even a $15-30 \%$ increase, likely adequate if implemented together with a deep reorganization (Table 1), would require years to be completed.

A critical analysis of what worked and what didn't should be a fundamental growth moment for doctors and society in general, improving our capacity to face emergencies. As Cicero said "Cuiusvis hominis est errare, nullius nisi insipientis in errore perseverare": any man can make a mistake, only a fool keeps making the same one.

\section{Springer}




\section{Table 1 Steps to prepare healthcare systems for next pandemic}

\begin{tabular}{|c|c|}
\hline Stand-alone ICU Emergency Hospitals & $\begin{array}{l}\text { To deal with an overwhelming influx of patients, adapting areas in the hospital buildings or positioning } \\
\text { field hospitals near close and connected to central hospitals have shown to work, whereas stand-alone } \\
\text { intensive care facilities or hospitals proved to be costly and useless }\end{array}$ \\
\hline Personal Protective Equipment Availability & $\begin{array}{l}\text { It is not acceptable that the Personal Protective Equipment are not available to the general population. The } \\
\text { World Health Organization and intensive care community have warned several times before about the } \\
\text { possibilities of a pandemic. However, most countries, including Italy, were unprepared. It is our responsi- } \\
\text { bility to press in this direction }\end{array}$ \\
\hline Territorial Medicine & $\begin{array}{l}\text { To control an epidemic, a strong public healthcare territory medicine service must be in place, and preven- } \\
\text { tion of the contagion must be implemented through appropriate identification and isolation of infected } \\
\text { subjects }\end{array}$ \\
\hline ICU Beds Availability & $\begin{array}{l}\text { Intensive care is the last link on a long chain; to provide the best care it must maintain its characteristics } \\
\text { and standards. In a harmonized framework, a 15-30\% increase in beds, staffed with adequate personnel } \\
\text { is likely to suffice, even in a severe pandemic }\end{array}$ \\
\hline
\end{tabular}

\section{Author details}

${ }^{1}$ Department of Anesthesia and Intensive Care, San Raffaele Hospital, Milan, Italy. ${ }^{2}$ Department of Anesthesiology, Intensive Care and Emergency Medicine, Medical University of Göttingen, Göttingen, Germany.

\section{Acknowledgements}

Open Access funding provided by Projekt DEAL.

\section{Compliance with ethical standards}

\section{Conflicts of interest}

The authors have no conflict of interest to disclose.

\section{Open Access}

This article is licensed under a Creative Commons Attribution-NonCommercial 4.0 International License, which permits any non-commercial use, sharing, adaptation, distribution and reproduction in any medium or format, as long as you give appropriate credit to the original author(s) and the source, provide a link to the Creative Commons licence, and indicate if changes were made. The images or other third party material in this article are included in the article's Creative Commons licence, unless indicated otherwise in a credit line to the material. If material is not included in the article's Creative Commons licence and your intended use is not permitted by statutory regulation or exceeds the permitted use, you will need to obtain permission directly from the copyright holder. To view a copy of this licence, visit http://creativecommons.org/licen ses/by-nc/4.0/.

\section{Publisher's Note}

Springer Nature remains neutral with regard to jurisdictional claims in published maps and institutional affiliations.

\section{Accepted: 25 May 2020}

Published online: 5 June 2020

\section{References}

1. Grasselli G, Zangrillo A, Zanella A, Antonelli M, Cabrini L, Castelli A, Cereda D, Coluccello A, Foti G, Fumagalli R, lotti G, Latronico N, Lorini L, Merler S, Natalini G, Piatti A, Ranieri MV, Scandroglio AM, Storti E, Cecconi M, Pesenti A, COVID-19 Lombardy ICU Network, Nailescu A, Corona A, Zangrillo A, Protti A, Albertin A, Forastieri Molinari A, Lombardo A, Pezzi A, Benini A, Scandroglio AM, Malara A, Castelli A, Coluccello A, Micucci A, Pesenti A, Sala A, Alborghetti A, Antonini B, Capra C, Troiano C, Roscitano C, Radrizzani D, Chiumello D, Coppini D, Guzzon D, Costantini E, Malpetti E, Zoia E, Catena E, Agosteo E, Barbara E, Beretta E, Boselli E, Storti E, Harizay F, Della Mura F, Lorini FL, Donato Sigurtà F, Marino F, Mojoli F, Rasulo F, Grasselli G, Casella G, De Filippi G, Castelli G, Aldegheri G, Gallioli G, Lotti G, Albano G, Landoni G, Marino G, Vitale G, Battista Perego G, Evasi G, Citerio G, Foti G, Natalini G, Merli G, Sforzini I, Bianciardi L, Carnevale L, Grazioli L, Cabrini L, Guatteri L, Salvi L, Dei Poli M, Galletti M, Gemma M, Ranucci M, Riccio M, Borelli M, Zambon M, Subert M, Cecconi M, Mazzoni MG, Raimondi M, Panigada M, Belliato M, Bronzini N, Latronico N, Petrucci N, Belgiorno N, Tagliabue P, Cortellazzi P, Gnesin P, Grosso P, Gritti P, Perazzo P, Severgnini P, Ruggeri P, Sebastiano P, Covello RD, Fernandez-Olmos R, Fumagalli R, Keim R, Rona R, Valsecchi R, Cattaneo S, Colombo S, Cirri S, Bonazzi S, Greco S, Muttini S, Langer T, Alaimo V, Viola U (2020) Baseline characteristics and outcomes of 1591 patients infected with SARS-CoV-2 admitted to ICUs of the Lombardy Region. Italy. JAMA 323(16):1574-1581. https://doi.org/10.1001/jama.2020.5394

2. Odone A, Delmonte D, Scognamiglio T, Signorelli C (2020) COVID-19 deaths in Lombardy, Italy: data in context. Lancet Public Health. https:// doi.org/10.1016/S2468-2667(20)30099-2

3. Adhikari NK, Fowler RA, Bhagwanjee S, Rubenfeld GD (2010) Critical care and the global burden of critical illness in adults. Lancet 376:1339-1346

4. Patroniti N, Zangrillo A, Pappalardo F, Peris A, Cianchi G, Braschi A, lotti GA, Arcadipane A, Panarello G, Ranieri VM, Terragni P, Antonelli M, Gattinoni $L$, Oleari F, Pesenti A (2011) The Italian ECMO network experience during the 2009 influenza $A(H 1 N 1)$ pandemic: Preparation for severe respiratory emergency outbreaks. Intensive Care Med 37:1447-1457 